\title{
PENGARUH DOSIS PUPUK ORGANIK CAIR TERHADAP PERTUMBUHAN DAN PRODUKSI FODDER PADI (ORYZA SATIVA) HIDROPONIK
}

\author{
Vian Dwi Chalisty ${ }^{a}$, Safita Kamelia ${ }^{b}$ \\ ${ }^{a}$ Program Studi Peternakan, Universitas Ma'arif Nahdlatul Ulama Kebumen, Indonesia \\ ${ }^{b}$ Mahasiswa Program Studi Peternakan, Universitas Ma'arif Nahdlatul Ulama Kebumen, \\ Indonesia \\ $\underline{\text { vian.chalisty@gmail.com }}^{a}$, safitakamelia31@gmail.com $^{b}$
}

\begin{abstract}
ABSTRAK
Fodder padi hidroponik dapat dijadikan sebagai alternatif teknologi untuk memproduksi pakan hijauan guna mangatasi kelangkaan pakan pada musim kemarau serta kurangnya lahan pakan ternak yang digunakan. Penelitian ini bertujuan untuk mengetahui pertumbuhan dan produksi dari fodder padi yang diberi penambahan dosis pupuk cair organik yang berbeda. Penelitian ini dirancang berdasarkan rancangan acak lengkap (RAL) dengan 4 perlakuan. Perlakuan pada penelitian ini, yaitu $\mathrm{P} 0=$ tanpa penambahan pupuk cair organik, $\mathrm{P} 1$ = penambahan dosis pupuk cair organik sebesar $30 \mathrm{~g}, \mathrm{P} 2=$ penambahan dosis pupuk cair organik sebesar $60 \mathrm{~g}$, dan P3 = penambahan dosis pupuk cair organik sebesar $90 \mathrm{~g}$. Sidik ragam menunjukkan bahwa pemberian dosis pupuk cair organik yang berbeda tidak menunjukkan pengaruh nyata $(\mathrm{P}>0,05)$ terhadap tinggi fodder padi, jumlah daun, dan produksi segar fodder padi. Rata-rata tinggi fodder padi hidroponik sebesar ( $\mathrm{P} 0=10,46 \pm 0,34),(\mathrm{P} 1=11,33 \pm 1,60),(\mathrm{P} 2=$ $10,45 \pm 0,50)$ dan $(\mathrm{P} 3=10,63 \pm 0,44)$. Jumlah daun fodder padi hidroponik sebesar ( $\mathrm{P} 0$ $=200,75 \pm 44,81),(\mathrm{P} 1=194,00 \pm 21,76),(\mathrm{P} 2=211,00 \pm 42,64)$ dan $(\mathrm{P} 3=$ 230,25 $\pm 44,93)$. Produksi segar fodder padi hidroponik sebesar $(\mathrm{P} 0=332,25 \pm 3,59)$, $(\mathrm{P} 1=340,50 \pm 7,93),(\mathrm{P} 2=337,00 \pm 11,43)$ dan $(\mathrm{P} 3=337,00 \pm 1,41)$. Berdasarkan hasil penelitian dapat disimpulkan bahwa penambahan dosis pupuk organik cair yang berbeda pada penanaman fodder padi hidroponik tidak berpengaruh signifikan terhadap tinggi fodder, jumlah daun, dan produksi segar fodder padi hidroponik. Hal ini kemungkinan disebabkan oleh beberapa faktor diantaranya penebaran benih yang kurang merata, pembentukan daun yang terjadi pada umur 5-6 hari penanaman, serta nutrien yang terkandung dalam media penanaman tidak terserap dengan baik.

Kata kunci: Tinggi Daun, Jumlah Daun, Produksi Segar, Hidroponik, Fodder Padi, Pupuk Cair Organik
\end{abstract}

\begin{abstract}
Hydroponic rice fodder can be used as an alternative technology to produce forage in order to overcome the feed scarcity in the dry season and the lack of land used for animal feed. This research was aimed to determine the growth and production of rice fodder given with the addition of different doses of organic liquid fertilizer. This research was designed based on a completely randomized design (CRD) with 4 treatments. The treatments in this research were $P O=$ without adding organic liquid fertilizer, $P 1=$ adding an organic liquid fertilizer dose of $30 \mathrm{~g}, P 2=$ adding an organic liquid fertilizer dose of $60 \mathrm{~g}$, and $P 3=$ adding an organic liquid fertilizer
\end{abstract}


dose of $90 \mathrm{~g}$. The variance test showed that different doses of organic liquid fertilizer showed no significant effect $(P>0.05)$ toward the rice fodder height, number of leaves, and fresh production of rice fodder. The average height of hydroponic rice fodder was $(P 0=10.46 \pm 0.34),(P 1=11.33 \pm 1.60),(P 2=10.45 \pm 0.50)$ and $(P 3=10.63 \pm 0.44)$. The number of hydroponic rice fodder leaves was $(P 0=200.75 \pm 44.81),(P 1=$ $194.00 \pm 21.76),(P 2=211.00 \pm 42.64)$ and $(P 3=230.25 \pm 44,93)$. Fresh production of hydroponic rice fodder was $(P 0=332.25 \pm 3.59),(P 1=340.50 \pm 7.93),(P 2=$ $337.00 \pm 11.43)$ and $(P 3=337.00 \pm 1,41)$. Based on the research results, it can be inferred that the addition of different doses of liquid organic fertilizer on hydroponic rice fodder planting has no significant effect on fodder height, number of leaves, and fresh production of hydroponic rice fodder. This may be caused by several factors including uneven seed distribution, leaves formation that occurs at the age of 5-6 days of planting, and the nutrients contained in the planting media are not absorbed properly.

Keywords: Leaves Height, Number of Leaves, Fresh Production, Hydroponics, Rice Fodder, Organic Liquid Fertilizer

\section{PENDAHULUAN}

Hijauan merupakan sumber pakan utama (>80\% dari total bahan kering) bagi ternak ruminansia untuk memenuhi kebutuhan hidup pokok, produksi dan reproduksi. Kebutuhan hijauan akan semakin meningkat seiring dengan bertambahnya jumlah populasi ternak yang dimiliki (Setiawan et al., 2020). Pemenuhan kebutuhan pakan hijauan dapat terkendala beberapa hal antara lain musim dan lahan sehingga ketersediaan pakan hijauan tidak tetap sepanjang tahun. Achmadi (2007) menyatakan bahwa kendala utama di dalam penyediaan hijauan pakan untuk ternak yaitu produksinya tidak tetap sepanjang tahun

Indonesia merupakan negara tropis yang memiliki dua musim yaitu musim kemarau dan hujan. Perubahan musim yang tidak seimbang sangat berpengaruh terhadap ketersediaan hijauan untuk pakan ternak. Saat musim hujan jumlah hijauan melimpah, sedangkan saat musim kemarau tanaman pakan tidak dapat tumbuh secara optimal sehingga jumlah hijauan sangat terbatas akibatnya ternak dapat mengalami kekurangan pakan hijauan.

Menurut Badan Meteorologi Klimatologi dan Geofisika yang dimuat dalam Berita Kebumen (2021), kekeringan di Kabupaten Kebumen pada tahun 2021 berada pada peringkat kedua di Indonesia yang paling panjang dan ekstrim. Hal tersebut berpengaruh pada kurangnya ketersediaan pakan hijauan di daerah Kabupaten Kebumen. Hal dapat berakibat pada pertumbuhan bobot sapi lambat, penurunan produksi susu, serta reproduksi dan kesehatannya terganggu. Sebagian besar peternak khususnya sapi di Kabupaten Kebumen, saat musim kemarau akan menggunakan jerami padi kering dari sisa panen untuk pakan ternak. Namun karena kadar ligninnya cukup tinggi, sehingga kecernaan jerami tetap lebih rendah dibandingkan hijauan pakan segar lainnya. 
Alternatif teknologi yang dapat dilakukan untuk menangani ketersediaan hijauan pakan secara kontinuitas dengan membuat pakan fodder. Menurut Ahmad (2011), fodder adalah tanaman yang diberikan pada ternak untuk menyediakan nutrisi yang diperlukan ternak. Pemberian fodder dapat berupa hijauan segar maupun kering, bentuk biji- bijian maupun umbi atau dalam bentuk silase. Tumbuhan fodder dapat diperoleh dari hasil budidaya maupun dari habitat alaminya di padangan. Padi merupakan tanaman yang mampu beradaptasi dengan baik meskipun terdapat faktor pembatas pertumbuhan dan produksi. Metode pengembangan pakan fodder dapat dilakukan secara hidroponik, yaitu menggunakan media air sebagai tempat hijauan pakan tumbuh. Fodder padi adalah alternatif baru bagi peternak berskala kecil dan memiliki lahan hijauan yang terbatas. Fodder padi hidroponik bisa disusun dalam rak-rak dan tidak memakan banyak tempat. Selain itu, padi yang ditanam dengan sistem hidroponik memiliki waktu pertumbuhan yang cepat sehingga dapat diproduksi dalam waktu singkat.

Salah satu hal terpenting dan yang harus diperhatikan dalam sistem penanaman secara hidroponik yaitu pemupukan. Pemupukan bertujuan mengganti unsur hara yang hilang dan menambah persediaan unsur hara yang dibutuhkan tanaman untuk meningkatkan produksi dan mutu tanaman. Ketersediaan unsur hara yang lengkap dan berimbang yang dapat diserap oleh tanaman merupakan faktor yang menentukan pertumbuhan dan produksi tanaman. Dua jenis pupuk yang terdapat di pasaran yaitu pupuk anorganik dan organik. Pupuk anorganik adalah pupuk hasil proses rekayasa secara kimia, fisik dan atau biologis dan merupakan hasil industri atau pabrik pembuat pupuk. Sedangkan pupuk organik adalah pupuk yang sebagian besar atau seluruhnya terdiri dari bahan organik yang berasal dari tanaman dan atau hewan yang telah melalui proses rekayasa, dapat dibentuk padat atau cair yang digunakan untuk mensuplai bahan organik, memperbaiki sifat fisik, kimia dan biologi tanah (Dewanto et al., 2013).

Pupuk A-B Mix biasa digunakan pada penanaman sistem hidroponik. Nutrisi A-B Mix atau pupuk racikan adalah larutan yang dibuat dari bahan-bahan kimia yang diberikan melalui media tanam, yang berfungsi sebagai nutrisi tanaman agar tanaman dapat tumbuh dengan baik. Nutrisi atau pupuk racikan mengandung unsur makro dan mikro yang dikombinasikan sedemikian rupa sebagai nutrisi (Pohan dan Oktoyournal, 2019). Alternatif pengganti A-B mix untuk memenuhi kebutuhan nutrisi pada tanaman hidroponik dapat menggunakan pupuk organik alam. Pupuk organik cair dapat digunakan sebagai sumber nutrien untuk meningkatkan pertumbuhan dan produktivitas tanaman (Marpaung et al., 2014). Penelitian ini bertujuan untuk mendapatkan dosis pupuk organik cair yang tepat untuk meningkatkan pertumbuhan dan produksi fodder padi hidroponik.

\section{METODOLOGI PENELITIAN}

Penelitian ini dilakukan pada bulan Juni sampai Juli 2021 di Desa Sidoagung, Kecamatan Sruweng, Kabupaten Kebumen, Jawa Tengah. Bahan yang digunakan dalam penelitian yaitu benih padi jenis Ciherang, air yang digunakan untuk perendaman atau 
penunjang pertumbuhan benih serta nutrisi tanam padi, pupuk organik cair yang digunakan dalam penelitian ini adalah pupuk organik cair Pandawa Subur. Kandungan dalam pupuk organik cair Pandawa Subur tertera pada Tabel 1.

Alat yang dilakukan dalam penelitian adalah timbangan analitik merek Logan dengan kepekaan 0,001 g, timbangan dengan kepekaan $1 \mathrm{~g}$ merk Camry, 16 nampan plastik yang digunakan untuk penampung air dan pupuk cair, 16 nampan plastik berlubang yang digunakan untuk tempat penanaman benih padi, kain flanel hitam, wadah tempat mengukur air 2 liter, rak tempat menaruh media penanaman, semprotan air, plastik kresek hitam, penggaris dan batang bambu yang sudah disesuaikan ukurannya untuk digunakan sebagai pembatas pada nampan berlubang pada saat proses germinasi.

Proses sortir biji padi dilakukan untuk mengidentifikasi dan mensortir biji yang tidak baik. Biji padi yang sudah disiapkan dimasukkan ke dalam wadah berisi air, kemudian direndam selama \pm 24 jam. Biji padi yang mengambang diambil lalu dibuang. Biji padi ditimbang sebanyak $150 \mathrm{~g}$ kemudian diletakkan ke dalam nampan yang sebelumnya sudah di alasi kain flanel dan diratakan. Biji padi disemprot sebanyak 4 kali sehari supaya kelembaban tetap terjaga selama 4 hari masa germinasi dengan air bersih. Tumpukan nampan yang berisi benih padi yang akan germinasi ditutup menggunakan plastik hitam sampai tumbuh tunas.

Tabel. 1. Kandungan Pupuk Cair Organik

\begin{tabular}{cc}
\hline $\begin{array}{c}\text { Parameter } \\
\text { (Parameter) }\end{array}$ & $\begin{array}{c}\text { Kandungan } \\
\text { (Content) }\end{array}$ \\
\hline $\mathrm{C}-$ organic & $2.34 \%$ \\
$\mathrm{C} / \mathrm{N}$ rasio & 0.28 \\
$\mathrm{pH} \mathrm{H} \mathrm{H}_{2}$ & 8.4 \\
$\mathrm{~N}-$ organic & 6.12 \\
$\mathrm{~N}-\mathrm{NH}_{4}$ & 1.31 \\
$\mathrm{~N}-\mathrm{NO}_{3}$ & 0.78 \\
$\mathrm{~N}$ Total & $8.21 \%$ \\
$\mathrm{P}_{2} \mathrm{O}_{5} \mathrm{Total}$ & $1.12 \%$ \\
$\mathrm{~K}_{2} \mathrm{O}$ Total & $0.12 \%$ \\
$\mathrm{C}_{\mathrm{a}} \mathrm{O}$ & $0.004 \%$ \\
$\mathrm{MgO}$ & $0.003 \%$
\end{tabular}

Sumber: Laboratorium Tanah, Tanaman, Pupuk, Air. Badan Penelitian dan Pembangunan Pertanian, Yogyakarta

Proses penanaman dimulai dengan mengukur pupuk organik cair sesuai dengan dosis yang ditentukan dan dicampur dengan air sebanyak 2 liter pada nampan selanjutnya dihomogenkan. Campuran air dan pupuk pada nampan diganti setiap pagi hari. Dosis pupuk organik cair yang digunakan yaitu: $\mathrm{PO}=$ pupuk cair organik dosis $0 \mathrm{~g} / 2$ liter air, P1 

= pupuk cair organik dosis $30 \mathrm{~g} / 2$ liter air, P2 = pupuk cair organik dosis $60 \mathrm{~g} / 2$ liter air, dan P3 = pupuk cair organik dosis $90 \mathrm{~g} / 2$ liter air. Setiap perlakuan penambahan pupuk cair organik dengan dosis yang berbeda akan dilakukan pengulangan sebanyak 4 kali

Pengukuran daun fodder dimulai pada hari ke -5 penelitian atau pada hari pertama penanaman fodder padi hidroponik dengan penambahan pupuk organik cair. Tinggi tanaman diukur menggunakan penggaris, dengan cara mengukur dari pangkal tanaman sampai pada daun yang paling tinggi, tiap tray atau nampan (Setiawan et al., 2020). Fodder padi dipanen pada umur 14 hari. Pada umumnya fodder jagung dengan usia 14 hari sudah dapat dipanen (Novinda et al., 2020). Selanjutnya, pada saat pemanenan dilakukan penimbangan berat akhir fodder padi serta perhitungan jumlah daun fodder padi hidroponik dalam sampel $5 \times 5 \mathrm{~cm}$.

Data yang diperoleh akan dianalisis menggunakan analisis variansi dengan rancangan Completely Randomized Designs pola searah (Steel and Torrie, 1993), dan dilanjutkan dengan uji rata-rata antar perlakuan dengan uji Duncan's pada perlakuan yang terdapat perbedaan yang nyata. Analisis data dilakukan menggunakan SPSS version 16.0 (Trihendradi, 2010)

\section{HASIL DAN PEMBAHASAN}

Hasil penelitian terhadap tinggi daun, jumlah daun dan produksi segar fodder padi dengan sistem hidropoinik dengan perlakuan penambahan pupuk organik cair dengan dosis yang berbeda dapat dilihat dalam Tabel 2

Tabel 2. Rataan Tinggi, Jumlah Daun, dan Produksi Segar Fodder Padi

\begin{tabular}{|c|c|c|c|}
\hline \multirow{2}{*}{$\begin{array}{l}\text { Perlakuan } \\
\text { (Treatment) }\end{array}$} & \multicolumn{3}{|c|}{$\begin{array}{c}\text { Paramete } \\
\text { (Parameter) }\end{array}$} \\
\hline & $\begin{array}{c}\text { Tinggi Fodder }(\mathrm{cm})^{\mathrm{ns}} \\
(\text { Height Fodder })\end{array}$ & $\begin{array}{c}\text { Jumlah Daun }^{\mathrm{ns}} \\
\text { (Number of Leaves) }\end{array}$ & $\begin{array}{c}\text { Produksi Segar (gram) } \\
\text { (Fresh Production) }\end{array}$ \\
\hline P0 (Kontrol) & $10,46 \pm 0,34$ & $200,75 \pm 44,81$ & $332,25 \pm 3,59$ \\
\hline $\mathrm{P} 1$ & $11,33 \pm 1,60$ & $194,00 \pm 21,76$ & $340,50 \pm 7,93$ \\
\hline $\mathrm{P} 2$ & $10,45 \pm 0,50$ & $211,00 \pm 42,64$ & $337,00 \pm 11,43$ \\
\hline P3 & $10,63 \pm 0,44$ & $230,25 \pm 44,93$ & $337,00 \pm 1,41$ \\
\hline
\end{tabular}

P1 = Pupuk Dosis $30 \mathrm{~g}$; P2 = Pupuk Dosis $60 \mathrm{~g}$; P3 = Pupuk Dosis $90 \mathrm{~g}$

${ }^{n s}$ tidak berbeda nyata

Tinggi fodder padi hidroponik dengan penambahan pupuk organik cair dengan dosis yang berbeda menunjukkan hasil yang berbeda tidak nyata. Rataan tinggi fodder padi dari yang tertinggi sampai yang terendah secara berurutan adalah P2, P1, P3 dan P0. Dachban (2010) menyatakan bahwa tinggi rendahnya pertumbuhan serta hasil tanaman dipengaruhi oleh dua faktor yaitu faktor internal dan faktor eksternal. Faktor internal merupakan faktor yang dipengaruhi oleh sifat genetik atau sifat turunan seperti usia 
tanaman, morfologi tanaman, daya hasil, kapasitas menyimpan cadangan makanan, ketahanan terhadap penyakit dan lain-lain. Faktor internal tidak berpengaruh pada tinggi fodder padi, karena jenis bibit yang digunakan dan waktu pemanenan fodder sama. Menurut Fahmi et al. (2013), faktor eksternal adalah faktor yang berasal dari luar tumbuhan atau faktor eksternal yang mencakup cahaya sinar matahari, kelembaban udara, nutrisi, kadar air, oksigen atau karbondioksida, $\mathrm{pH}$ atau derajat keasaman, kepadatan populasi, dan media tanam tumbuhan.

Faktor lain yang mempengaruhi tinggi tanaman fodder padi adalah jarak penyebaran benih pada keranjang. Penebaran benih pada keranjang yang kurang merata menyebabkan beberapa benih padi saling bertumpuk sehingga mengakibatkan pertumbuhan fodder kurang optimal. Hal ini sesuai dengan pernyataan Hartanti dan Jayantika (2016), yang menyatakan bahwa, selain sifat genetik dan lingkungan yang berpengaruh terhadap tinggi tanaman, pemakaian jarak tanam yang lebar dan jumlah bibit juga merupakan faktor penting bagi tanaman karena pengaturan jarak tanam yang lebar akan memberi ruang bagi tanaman dan jumlah bibit yang disesuaikan dengan karakter tanaman agar tidak terjadi perebutan sinar matahari, nutrisi dan air bagi tanaman sehingga pertumbuhan tanaman padi bisa tumbuh secara optimal.

Jumlah daun fodder padi hidroponik dengan penambahan pupuk organik cair dengan dosis yang berbeda menunjukkan hasil yang berbeda tidak nyata. Rataan jumlah fodder padi dari yang paling banyak sampai yang paling sedikit secara berurutan adalah P3, P2, P0 dan P1. Salah satu faktor yang mungkin mempengaruhi hasil rataan jumlah daun berbeda tidak nyata adalah pembentukan daun pada fodder padi relatif sama yaitu antara 56 hari penanaman. Hal ini menyebabkan pertumbuhan fodder padi Setelah umur -6 hari penanaman hanya pada lebar daun dan sedikit pertambahan panjang pada daun bukan bertambah jumlah daun dalam satu batang. Jumlah daun yang terdapat pada batang fodder padi berkisar antara 2-3 helai perbatang fodder. Hal ini berbeda dengan pendapat Subekti et al. (2010) menyatakan bahwa daun pertama mulai muncul setelah tanaman umur 9 hari. Jumlah daun berhubungan dengan pertumbuhan batang atau tinggi tanaman dimana batang tersusun dari ruas yang merentang di antara buku-buku batang tempat melekatnya daun semakin tinggi tanaman semakin banyak pula jumlah daun pada tanaman tersebut. Pernyataan ini didukung oleh Napitulu dan Damanhuri (2018), padi merupakan golongan tumbuhan Gramineae yang memiliki batang beruas-ruas dan bersifat merumpun.

Produksi segar fodder padi hidroponik dengan penambahan pupuk organik cair dengan dosis yang berbeda menunjukkan hasil yang berbeda tidak nyata. Hasil ini berbeda dengan penelitian yang dilakukan oleh Kustyorini et al. (2020) bahwa frekuensi penyiraman pupuk organik cair dengan konsentrasi sebesar $10 \%$ berpengaruh sangat nyata terhadap produksi segar fodder gandum. Perbedaan tersebut mungkin diakibatkan karena konsentrasi dosis pupuk cair organik yang rendah sehingga unsur hara dimana pupuk cair organik yang diaplikasikan pada fodder padi, nutrisinya tidak dapat diserap dengan baik 
oleh fodder padi. Sejalan dengan pendapat Rizqiani et al. (2006) menjelaskan bahwa tanaman membutuhkan unsur hara untuk melakukan proses-proses metabolisme, terutama pada masa vegetatif. Menurut Marsono dan Sigit (2001), unsur hara makro dan mikro sangat dibutuhkan oleh tanaman, terutaman diperlukan untuk membentukan klorofil yang diperlukan dalam proses fotosintesis dan memacu pertumbuhan vegetatif tanaman, phosphor $(\mathrm{P})$ berperan membentukan batang dan daun, sehingga dapat memenuhi kebutuhan tanaman, sedangkan kalium $(\mathrm{K})$ berperan sebagai pengatur proses fisiologis tanaman seperti fotosintesis, akumulasi, translokasi, transportasi karbohidrat, membuka membentuk stomata, atau mengatur distribusi air dalam jaringan dan sel.

\section{KESIMPULAN}

Hasil penelitian menunjukkan bahwa penambahan dosis pupuk organik cair yang berbeda pada penanaman fodder padi hidroponik tidak berpengaruh signifikan terhadap tinggi fodder, jumlah daun, dan produksi segar fodder padi. Hal ini disebabkan oleh beberapa faktor diantaranya penebaran benih yang kurang merata, pembentukan daun yang terjadi pada umur 5-6 hari penanaman, serta nutrien yang terkandung dalam media penanaman tidak terserap dengan baik.

\section{DAFTAR PUSTAKA}

Achmadi, J. (2007). Kualitas Pakan Ternak Yang Baik dan Aman untuk Mendukung Kesuksesan Usaha Peternakan. Unggahan: Balai Pengujian Mutu Pakan Ternak Direktorat dan Jenderal Peternakan dan Kesehatan Hewan Kementerian Pertanian.

Ahmad, K. (2011). Fodder Plants, Everything You Want to Know - A Featured Article. London: Longman Inc.

Berita Kebumen. (2021, 4 Juni). BMKG Sebut Kemarau Kebumen Masuk Kategori Ekstrem. Diperoleh 11 September 2021, dari https://www.beritakebumen.co.id/2021/06/bmkg-sebut-dampak-kemarau-kebumenmasuk.html.

Dachban, S. M. B. dan M. Y. Dibisono. (2010). Pengaruh Sistem Tanam, Varietas, Jumlah Bibit Terhadap Pertumbuhan dan Hasil Padi Sawah (Oryza sativa L.). Jurnal Ilmiah Pendidikan Tinggi. 3 (1) : 47 - 57.

Dewanto, F. G., Londok, J. J. M. R., Tuturoong, R.A.V., dan Kaunang, W. B. (2013). Pengaruh Pemupukan Anorganik dan Organik Terhadap Produksi Tanaman Jagung Sebagai Sumber Pakan. (Versi elektronik). Jurnal Zootek, 32 (5). 1-8.

Fahmi, A., Syamsudin., Utami, S. N. H., dan Radjagukguk, B. (2013). Pengaruh Interaksi Hara Nitrogen Dan Fosfor Terhadap Pertumbuhan Tanaman Jagung (Zea mays L) Pada Tanah Regosol dan Latosol. Berita Biologi. 10 (3). 297-304. 
Jurnal Sains Peternakan Nusantara

Hartanti, A. dan Jayantika. R. (2017). Induksi Pertumbuhan dan Hasil Tanaman Padi (Oryza Sativa) Varietas Ir64 Dengan Aplikasi Jarak Tanam dan Jumlah Bibit Per Titik Tanam. (Versi elektronik). AGROTECHBIZ. 04.(01). 35-43.

Kustyorini, T. I. W., Hadiani, D. P. P., dan Sardin, P. (2020). Frekuensi Penyiraman Pupuk Organik Cair Terhadap Produksi Segar dan Bahan Kering Hidroponik Fodder Gandum (Triticum Sp) (Versi elektronik). Jurnal Sains Peternakan. 8 (2): 132-137.

Marpaung, A. E., Karo, B., dan Tarigan, R. (2014). Pemanfaatan Pupuk Organik Cair dan Teknik Penanaman Dalam Peningkatan Pertumbuhan dan Hasil Kentang (Teh Utilization of Liquid Organic Fertilizer and Planting Techniques for Increasing teh Potato Growth and Yielding). J. Hort. 24 (1): 49-55, 2014.

Marsono dan Sigit. 2001. Petunjuk Penggunaan Pupuk. Penebar Swadaya, Jakarta.

Napitupulu. M dan Damanhuri. (2018). Keragaman Genetik, Fenotipe dan Heritabilitas pada Generasi F2 Hasil Persilangan Tanaman Padi (Oryza sativa L.). Jurnal Produksi Tanaman. 6.(8). 1844-1850.

Novianda., Fajar, B. L. dan Fitria, L. (2020). Penerapan Budidaya Fodder Jagung Dengan Sistem Penyiraman Timer Digital Otomatis Sebagai Pakan Kambing Etawa dan Domba Pada Kelompok Tani Di Desa Benua Raja Aceh Tamiang (Versi elektronik). Global Science Society. 2(1). 310-317.

Pohan, S. A., dan Oktoyournal, O. (2019). Pengaruh Konsentrasi Nutrisi A-B Mix Terhadap Pertumbuhan Caisim Secara Hidroponik (Drip system). LUMBUNG. 18(1), 20-32. https://doi.org/10.32530/lumbung.v18i1.179.

Rizqiani, N. F. Ambarwati, E., dan Yuwono, N. W. (2006). Pengaruh Dosis dan Frekuensi Pemberian Pupuk Organik Cair terhadap Pertumbuhan dan Hasil Buncis (Phaseolus vulgaris L.) Dataran Rendah. Ilmu Pertanian. 12 (2).163-178.

Setiawan, F. B., Astuti, N., dan Rasminati, N. (2020). Pengaruh Umur Panen Terhadap Produksi Fodder Jagung (Zea mays) (Versi elektronik). Fakultas Agroindustri Universitas Mercu Buana Yogyakarta. 8 (1), 1.

Steel, R.G.D. and J.H. Torrie. 1993. Prinsip dan Prosedur Statistika Suatu Pendekatan Biometrik, Terjemahan. PT Gramedia, Jakarta.

Subekti N. A., Syafruddin, Roy E., dan Sri S. 2010. Morfologi Tanaman dan FasemPertumbuhan Jagung. Balai Penelitian Tanaman Serealia. Maros. Hal 16-27.

Trihendradi, C. 2010. Step by Step SPSS 18 Analisis Data Statistik. Penerbit Andi. Yogyakarta. 
Jurnal Sains Peternakan Nusantara Pengaruh Dosis Pupuk Organik Cair Terhadap Pertumbuhan dan Produksi Fodder Padi (Oryza Sativa)

Hidroponik

EISSN: 2807-9361

Volume 01 Nomor 02 Desember 2021 